\title{
Clinical evaluation of autologous fat graft for facial deformity: a case series study
}

\author{
Mansour Khorasani ${ }^{1}$, Pejman Janbaz ${ }^{2}$ \\ ${ }^{1}$ Department of Oral and Maxillofacial Surgery, Faculty of Dentistry, Tehran University of Medical Sciences, Tehran, \\ ${ }^{2}$ Department of Oral and Maxillofacial Surgery, Faculty of Dentistry, Qazvin University of Medical Sciences, Qazvin, Iran
}

\begin{abstract}
J Korean Assoc Oral Maxillofac Surg 2021;47:286-290)
Objectives: The use of fat grafts in maxillofacial sculpturing is currently a common technique. Unlike fillers, autologous fats unite with facial tissues, but long-term results may still be unsatisfactory. Sharing long-term follow-ups can be helpful in making outcomes more predictable.

Materials and Methods: The data from patients who were admitted from 2014 to 2016 for fat augmentation were collected. In all cases, fat grafts were injected by blunt cannula using a tunneling technique in different planes. A fan shape order for the malar, periorbital, nasolabial fold, mandibular angle and body, and perioral area was established.

Results: Autologous fat was used for different sites of the maxillofacial regions. Of 15 patients, two patients were not satisfied due to fat graft resorption. For this, further injections were performed six months after the first injection using preserved fat grafts. One patient continued to be dissatisfied. There were no other complications related to fat transplants.

Conclusion: Fat transplantation is a safe, reliable, and non-invasive method for facial contour and facial soft tissue defect restoration. Additional methods such as mesenchymal stem cells along with fat injection increase the survival rate of transferred fat.
\end{abstract}

Key words: Transplantation, Autologous, Adipose tissue, Facial asymmetry, Autografting

[paper submitted 2020. 11. 10 / revised 2020. 12. 8 / accepted 2020. 12. 11]

\section{Introduction}

Congenital abnormalities, aging, and trauma can cause soft tissue deformities. There are several types of injectable materials that are used for facial deformity correction and facial rejuvenation. One of the common and preferred methods is autologous fat transfer which has recently become a popular procedure ${ }^{1}$. The procedure was first performed in 1893 by a plastic surgeon, Gustav Neuber. He used autologous arm fat to correct a periorbital osteomyelitis scar ${ }^{2}$. Autologous fat transplantation is a non-invasive method for soft tissue volume loss management ${ }^{3}$.

Unlike other non-autologous fillers, autologous fat is a

\section{Pejman Janbaz}

Department of Oral and Maxillofacial Surgery, Faculty of Dentistry, Qazvin University of Medical Sciences, Bahonar Blvd., Qazvin 34199-15315, Iran TEL: +98-9122810716

E-mail:pejmanjanbaz@yahoo.com

ORCID: https://orcid.org/0000-0002-0942-1325

(c) This is an open-access article distributed under the terms of the Creative Commons Attribution Non-Commercial License (http://creativecommons.org/ licenses/by-nc/4.0/), which permits unrestricted non-commercial use, distribution, and reproduction in any medium, provided the original work is properly cited.

Copyright (C) 2021 The Korean Association of Oral and Maxillofacial Surgeons. long-lasting filler that unites with facial tissues and is welltolerated ${ }^{4}$. Also, in some cases, autologous fat transfer is a complementary procedure to a facelift to improve facial contour ${ }^{4,5}$. Over-treatment, fatty cyst development, fat hypertrophy, fat calcification, and fat embolism are complications of fat injection ${ }^{3}$. Additionally, the procedure may require "touching up" for better results.

This report reviews the use of autologous fat in maxillofacial reconstruction in 15 patients with malar and periorbital area, nasolabial fold, mandibular angle and body, and perioral area defects. These defects arise in cases such as trauma and congenital deformity that require aesthetic improvement.

\section{Materials and Methods}

In this study, the data from the patients who were admitted from 2014 to 2016 in Department of Oral and Maxillofacial Surgery, Faculty of Dentistry, Qazvin University of Medical Sciences for trauma defect revision and face augmentation by fat transplants were collected. All patients had been informed about the advantages and possible complications of treat- 
ment and signed a formal informed consent for treatment. All patients had the opportunity to ask questions and discuss the advantages and disadvantages of the procedure. This study was approved by the ethical committee of Qazvin University of Medical Sciences with ethical number IR.QUMS. REC.1399.230. There is no conflict with ethical considerations.

Before harvest, the region was injected by a tumescent solution ( $0.5 \%$ lidocaine $+0.0005 \%$ epinephrine). After 15 minutes, the fat was harvested by a syringe with low negative pressure (0.75-1.0 atmosphere) and blunt tip cannula (2.1-2.4 $\mathrm{mm}$ ) through a stab incision on the abdomen or thigh. After processing, harvested fats were injected using $1 \mathrm{cc}$ insulin syringes and blunt cannulas (0.7-1.2 mm tip) using a tunneling technique in different planes from deep to surface in fan shape order in the malar and periorbital area, nasolabial fold, mandibular angle and body, and perioral area.(Fig. 1) For malar augmentation, the fat was injected subcutaneously through an incision lateral to the nasolabial fold, as well as via a second incision on the zygomatic arch. The fat was placed near the zygomatic bone, as well as beneath, into, and superficial to the zygomaticus muscles and subcutaneous

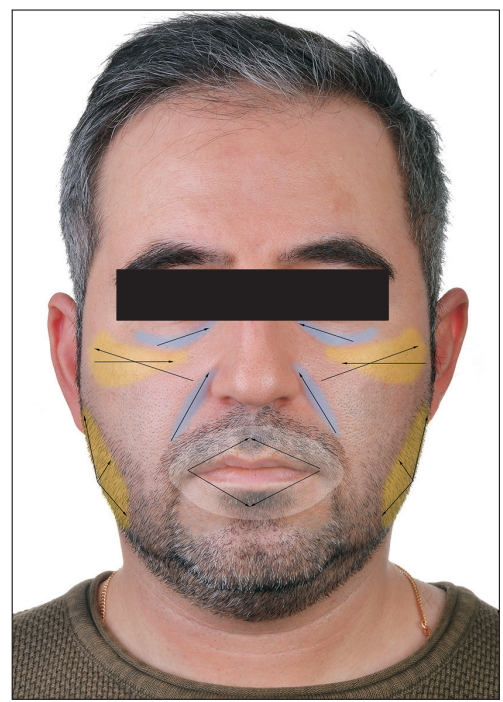

Fig. 1. An illustrative figure of injection technique showing the directions and areas.

Mansour Khorasani et al: Clinical evaluation of autologous fat graft for facial deformity: a case series study. J Korean Assoc Oral Maxillofac Surg 2021

Table 1. Reason of fat transplantation

\begin{tabular}{lc}
\hline \multicolumn{1}{c}{ Reason for fat transferring } & No. of cases $(\%)$ \\
\hline Aesthetic & $13(86.7)$ \\
Asymmetry following trauma & $1(6.7)$ \\
Asymmetry following nerve paralysis & $1(6.7)$ \\
\hline
\end{tabular}

Mansour Khorasani et al: Clinical evaluation of autologous fat graft for facial deformity: a case series study. J Korean Assoc Oral Maxillofac Surg 2021 space. For the periorbital area, fat aliquots were transferred to multiple levels, including subcutaneous, intramuscular, and submuscular. Each nasolabial fold was injected through a lateral incision with feathering on the edges. For the angle and body of the mandible, the jawlines were augmented in the superior, oblique, and anterior directions through an incision on the angle area. The level of injection varies from subcutaneous and supra muscular on the masseter, to slightly deep on the anterior edge of the masseter. For the perioral area, the lip was approached through a lateral incision and a submucosal plan to reach a satisfactory volume.

The indications for fat transplantation in our clinic were:

Table 2. Injection sites

\begin{tabular}{lc}
\hline \multicolumn{1}{c}{ Region } & No. of cases $(\%)$ \\
\hline Malar and periorbital area & $12(80.0)$ \\
Nasolabial fold & $5(33.3)$ \\
Angle and body of mandible & $2(13.3)$ \\
Perioral area & $2(13.3)$ \\
\hline
\end{tabular}

Mansour Khorasani et al: Clinical evaluation of autologous fat graft for facial deformity: a case series study. J Korean Assoc Oral Maxillofac Surg 2021
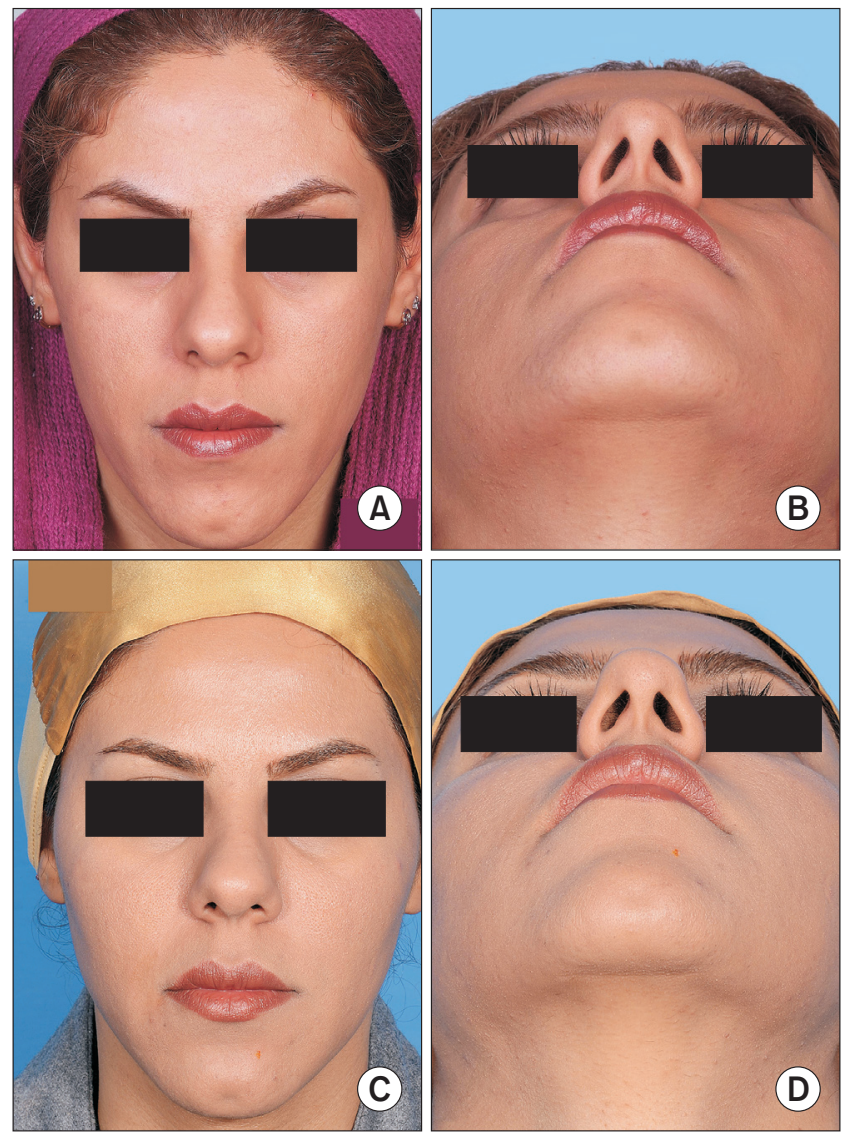

Fig. 2. Malar area, infraorbital rim, and nasolabial fold augmentation. A, B. Preoperative views. C, D. Postoperative views. Mansour Khorasani et al: Clinical evaluation of autologous fat graft for facial deformity: a case series study. J Korean Assoc Oral Maxillofac Surg 2021 
aesthetic $(86.7 \%)$, asymmetry following trauma (6.7\%), and asymmetry following nerve paralysis $(6.7 \%)$.(Table 1$)$ The autologous fat was used for different maxillofacial region sites: malar and periorbital $(80.0 \%)$, nasolabial fold (33.3\%), mandibular angle and body (13.3\%), and perioral area (13.3\%).(Table 2)

\section{Case 1}

A 26-year-old female patient with a chief complaint of long face, malar flattening, and deep nasolabial fold. Autologous fat harvested from the abdomen was transplanted to the malar area, infraorbital rim, and nasolabial fold.(Fig. 2)

\section{Case 2}

A 45-year-old female patient with a chief complaint of right malar depression, thin upper and lower lips, and inadequate vermilion exposure following facial nerve paralysis. The defects were corrected and formed by fat harvested from the abdomen.(Fig. 3)

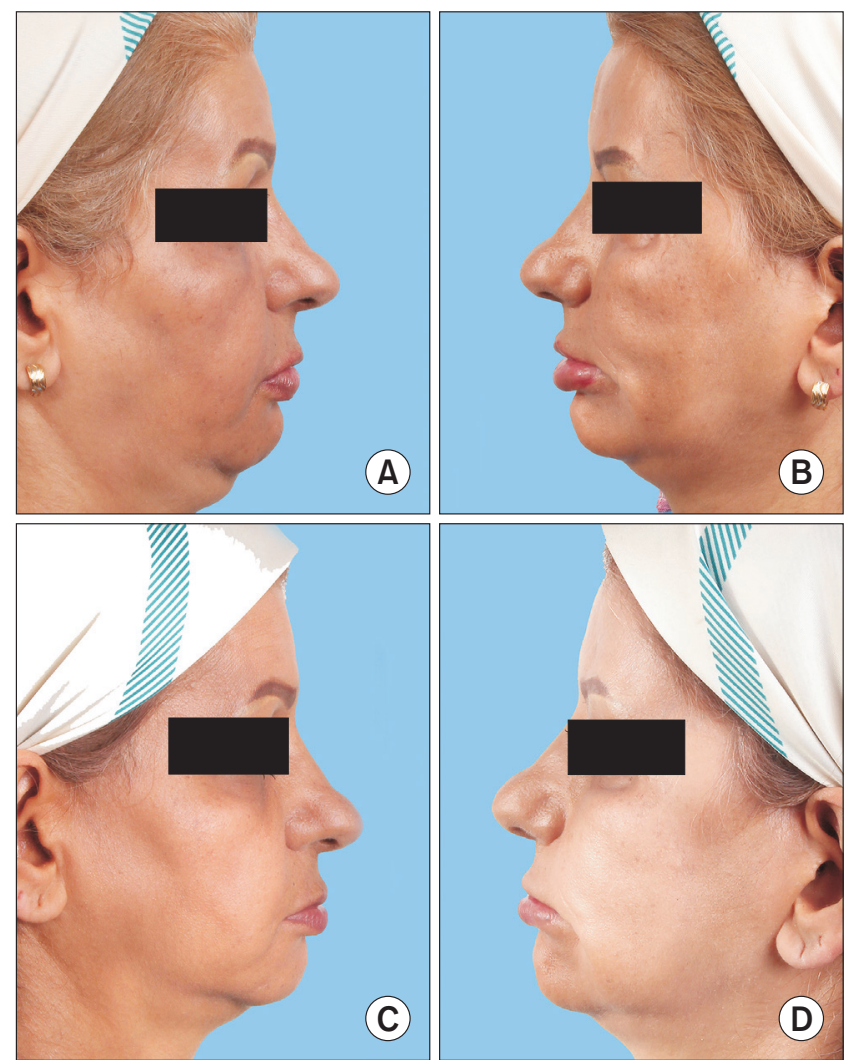

Fig. 3. Right malar depression, thin upper and lower lips. A, B. Preoperative views. C, D. Postoperative views.

Mansour Khorasani et al: Clinical evaluation of autologous fat graft for facial deformity: a case series study. J Korean Assoc Oral Maxillofac Surg 2021

\section{Case 3}

A 35-year-old female patient with depressed right malar area following trauma, a candidate for malar augmentation by fat transferring. The depression was corrected by fat from the abdomen.(Fig. 4)

\section{Results}

A summary of patients are shown in Table 3. The data from 15 patients including 13 female and two male were retrieved. Of all cases, $80.0 \%$ had malar flattening, 33.3\% had deep nasolabial fold, $13.3 \%$ had mandibular asymmetry, and 13.3\% of cases also had perioral wrinkles and inadequate vermillion exposure. One patient $(6.7 \%)$ had soft tissue depression due to surgical scarring, and one patient $(6.7 \%)$ had soft tissue atrophy due to facial nerve paralysis.

Of 15 patients, two were not satisfied due to fat graft resorption, and further injections were performed six months
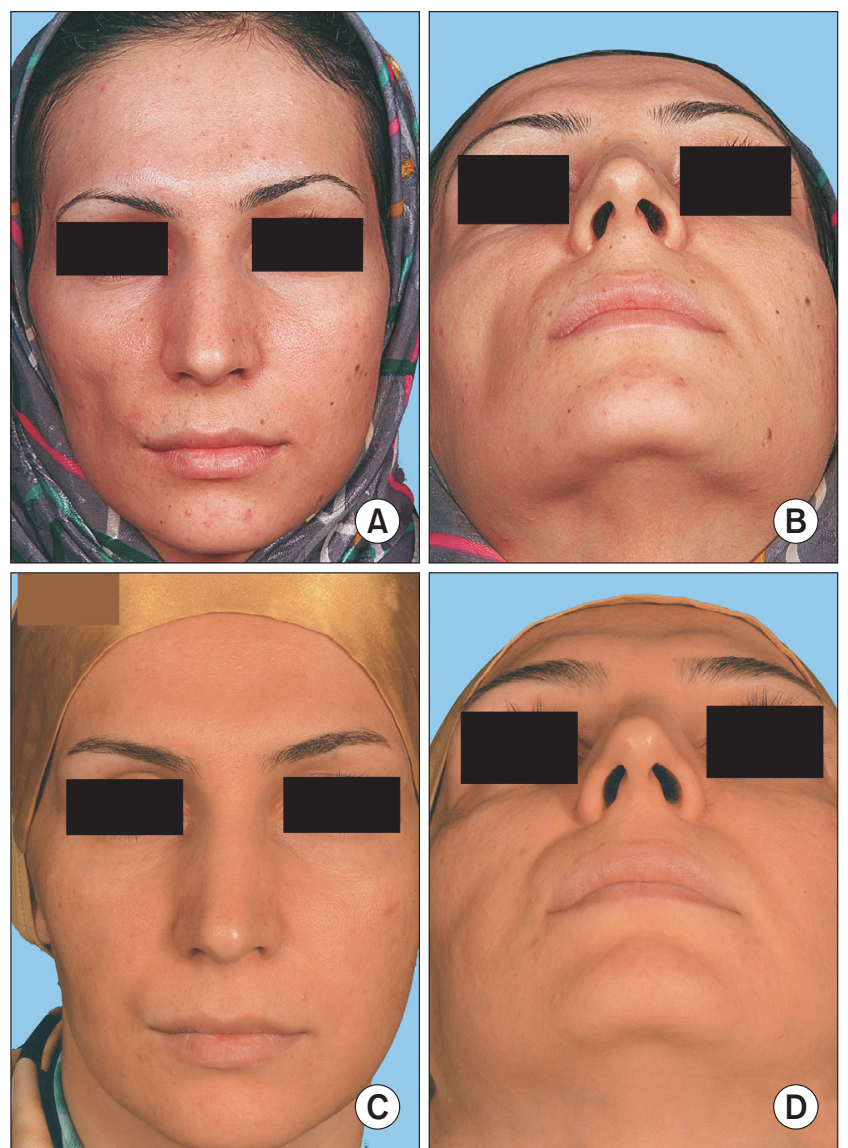

Fig. 4. Right malar area augmentation. A, B. Preoperative views. C, D. Postoperative views.

Mansour Khorasani et al: Clinical evaluation of autologous fat graft for facial deformity: a case series study. J Korean Assoc Oral Maxillofac Surg 2021 
Table 3. Summary of patients

\begin{tabular}{|c|c|c|c|c|c|c|c|c|}
\hline No. & $\begin{array}{l}\text { Age } \\
(\mathrm{yr})\end{array}$ & Sex & Site of injection & $\begin{array}{l}\text { Amount of } \\
\text { augmentation } \\
(\mathrm{mL})\end{array}$ & $\begin{array}{c}\text { Follow-up } \\
(\mathrm{yr})\end{array}$ & Complication & Corrective & $\begin{array}{c}\text { Patient } \\
\text { satisfaction }\end{array}$ \\
\hline 1 & 26 & $\mathrm{~F}$ & Malar-nasolabial fold & 40 & 4 & No & No & Yes \\
\hline 2 & 20 & $\mathrm{~F}$ & Malar & 30 & 4 & No & No & Yes \\
\hline 3 & 40 & $\mathrm{~F}$ & $\begin{array}{l}\text { Angle and body of mandible- } \\
\text { nasolabial fold }\end{array}$ & 35 & 4 & No & No & Yes \\
\hline 4 & 45 & $\mathrm{~F}$ & Malar-lateral part of lip & 40 & 3 & $\begin{array}{c}\text { Yes } \\
\text { (resorption) }\end{array}$ & $\begin{array}{l}\text { Second fat } \\
\text { transferring }\end{array}$ & Yes \\
\hline 5 & 28 & $\mathrm{~F}$ & Malar & 30 & 3 & No & No & Yes \\
\hline 6 & 23 & $\mathrm{~F}$ & Malar-nasolabial fold & 30 & 3 & No & No & Yes \\
\hline 7 & 25 & $\mathrm{~F}$ & Malar & 25 & 3 & No & No & Yes \\
\hline 8 & 35 & M & Malar & 30 & 3 & No & No & Yes \\
\hline 9 & 32 & $\mathrm{~F}$ & Malar & 25 & 3 & No & No & Yes \\
\hline 10 & 26 & $\mathrm{~F}$ & Angle and body of mandible & 22 & 3 & $\begin{array}{c}\text { Yes } \\
\text { (resorption) }\end{array}$ & $\begin{array}{l}\text { Second fat } \\
\text { transferring }\end{array}$ & No \\
\hline 11 & 28 & $\mathrm{~F}$ & Malar & 20 & 3 & No & No & Yes \\
\hline 12 & 31 & $\mathrm{~F}$ & Malar & 25 & 3 & No & No & Yes \\
\hline 13 & 29 & $\mathrm{~F}$ & Nasolabial fold-lips & 15 & 2 & No & No & Yes \\
\hline 14 & 41 & M & Malar & 20 & 2 & No & No & Yes \\
\hline 15 & 33 & $\mathrm{~F}$ & Malar-nasolabial fold & 30 & 2 & No & No & Yes \\
\hline
\end{tabular}

(F: female, M: male)

Mansour Khorasani et al: Clinical evaluation of autologous fat graft for facial deformity: a case series study. J Korean Assoc Oral Maxillofac Surg 2021

after the first injection using preserved fat grafts. One patient continued to be dissatisfied with the final results. There were no other complications related to fat transplants.

\section{Discussion}

The primary manifestations of aging are subdermal tissue loss, fat atrophy, and vertical displacement of the tissues ${ }^{2,6,7}$. Reduced skin elasticity and underlying bone loss are two important factors affecting mid-face aging. The first successful free fat transplantation was reported by Neuber in $1893^{2}$. In 1909, Hollander introduced a technique using a cannula for fat injections. In 1990, Coleman introduced centrifuge use in the fat processing technique ${ }^{8}$.

To regain volume, morphology, and contour of facial deformities, there are several injectable fillers available in the market such as hyaluronic acid-based fillers, Restylane, calcium hydroxyapatite, and poly L-lactic acid. However, while the results are predictable and satisfactory, these fillers are only appropriate for short-term use ${ }^{9}$.

Autologous fat is biocompatible, available in large amounts, economically cost-effective, and has long-lasting results in comparison with other fillers. Autologous fat transplantation is one of the best options suggested in tissue augmentation? ${ }^{9}$. An autologous fat graft is a vital tissue, and there are no concerns about antigenicity and possible infection. Additionally, a fat graft has the ability to promote host tissue repair.

However, while being a reliable method for improving facial morphology, autologous fat transfer is a sensitive, challenging technique ${ }^{7,10}$. Since the fat graft is a vital tissue, the graft has the potential for atrophy and/or hypertrophy; therefore, further injections may be required. According to Xie et al.'s study ${ }^{10}$, long-term outcome can be expected after one to three injections. This research group reported $73.5 \%$ complete satisfaction and $4.5 \%$ dissatisfaction among their patients ${ }^{10}$. In our patients, $93.3 \%$ of patients were completely satisfied, $13.3 \%$ of patients needed further injections, and one patient $(6.7 \%)$ was not completely satisfied.

The fat transplant must be performed with minimum tissue trauma ${ }^{6}$, and fat processing is a sensitive phase that is critical for fat cells' survival ${ }^{7}$. Coleman and $\mathrm{Katzel}^{8}$ suggested fat harvesting by using a $10 \mathrm{~mL}$ syringe to minimize soft tissue trauma and blunt cannulas for fat transfer to avoid intravascular injection. This method of injection also minimizes resorption, necrosis, cyst formation, and large fat drops (larger than $0.1 \mathrm{~mL})^{8}$. In a review of 550 articles, 596 patients received fat grafts; the survival rate for autologous fat graft in the breast area was $30 \%-83 \%$. Based on an animal study, fat graft survival rate after one year follow-up in rabbits was about $14 \%-14.5 \%{ }^{11}$. Protocols like insulin injection, adiposederived stem cells, and hyperbaric oxygen were effective in fat cell survival improvement $(79.16 \% \text { after } 4 \text { weeks })^{12}$. Methods like platelet-rich plasma (69\%-77\% fat cell survival after 1 year $)^{13,14}$, progenitor-supplemented adipose tissue (56\% fat cell survival after 6 months $)^{15}$, and mesenchymal stem cells $(82 \% \text { fat cell survival after } 1 \text { year })^{16}$ were effective in improving fat cell durability. Tanna et al. ${ }^{17}$ achieved $83 \%$ fat durability in soft tissue reconstruction in cases of craniofacial microsomia. Rare, but possible, complications related to autologous fat graft include vision loss, cerebrovascular 
accident, ophthalmic artery embolism, middle cerebral artery embolism, and even death ${ }^{11}$.

\section{Conclusion}

Fat transplantation is a safe, reliable, and non-invasive method for facial contour and facial soft tissue defect restoration. Occasionally multiple fat injections are required. Additional methods such as use of mesenchymal stem cells along with fat injection increase the survival rate of transferred fat.

\section{ORCID}

Mansour Khorasani, https://orcid.org/0000-0003-3710-2556

Pejman Janbaz, https://orcid.org/0000-0002-0942-1325

\section{Authors' Contributions}

M.K. organized the survey, designed the study, and treated the patients together with P.J. M.K. revised the manuscript. All authors read and approved the final manuscript.

\section{Ethics Approval and Consent to Participate}

This study was approved by the ethical committee of Qazvin University of Medical Sciences with ethical number IR.QUMS.REC.1399.230. All patients signed a formal informed consent for treatment.

\section{Consent for Publishing Photographs}

Written informed consent was obtained from the patients for publication of this article and accompanying images.

\section{Conflict of Interest}

No potential conflict of interest relevant to this article was reported.

\section{References}

1. Winters R, Moulthrop T. Is autologous fat grafting superior to other fillers for facial rejuvenation? Laryngoscope 2013;123:1068-9. https://doi.org/10.1002/lary.23614

2. Stallworth CL, Wang TD. Fat grafting of the midface. Facial Plast Surg 2010;26:369-75. https://doi.org/10.1055/s-0030-1265020
3. Vyas HJ, Sohn AM, Costello BJ. Liposuction and fat transfer techniques. In: Fonseca RJ, ed. Oral and maxillofacial surgery. 3rd ed. St. Louis: Elsevier; 2018:429-38.

4. Marten TJ, Elyassnia D. Fat grafting in facial rejuvenation. Clin Plast Surg 2015;42:219-52. https://doi.org/10.1016/ j.cps.2014.12.003

5. Lam SM, Glasgold RA, Glasgold MJ. Fat harvesting techniques for facial fat transfer. Facial Plast Surg 2010;26:356-61. https://doi. org/10.1055/s-0030-1265016

6. Tzikas TL. Lipografting: autologous fat grafting for total facial rejuvenation. Facial Plast Surg 2004;20:135-43. https://doi. org $/ 10.1055 / \mathrm{s}-2004-861754$

7. Sykes JM, Tapias V, Pu LL. Autologous fat grafting viability: lower third of the face. Facial Plast Surg 2010;26:376-84. https://doi. org/10.1055/s-0030-1265025

8. Coleman SR, Katzel EB. Fat grafting for facial filling and regeneration. Clin Plast Surg 2015;42:289-300, vii. https://doi.org/10.1016/ j.cps.2015.04.001

9. Minton TJ, Williams EF. Lipotransfer in the upper third of the face. Facial Plast Surg 2010;26:362-8. https://doi.org/10.1055/s-00301265018

10. Xie Y, Zheng DN, Li QF, Gu B, Liu K, Shen GX, et al. An integrated fat grafting technique for cosmetic facial contouring. J Plast Reconstr Aesthet Surg 2010;63:270-6. https://doi.org/10.1016/ j.bjps.2008.11.016

11. Yu NZ, Huang JZ, Zhang H, Wang Y, Wang XJ, Zhao R, et al. A systemic review of autologous fat grafting survival rate and related severe complications. Chin Med J (Engl) 2015;128:1245-51. https://doi.org/10.4103/0366-6999.156142

12. Matsumoto D, Sato K, Gonda K, Takaki Y, Shigeura T, Sato T, et al. Cell-assisted lipotransfer: supportive use of human adiposederived cells for soft tissue augmentation with lipoinjection. Tissue Eng 2006;12:3375-82. https://doi.org/10.1089/ten.2006.12.3375

13. Gentile P, Orlandi A, Scioli MG, Di Pasquali C, Bocchini I, Curcio $\mathrm{CB}$, et al. A comparative translational study: the combined use of enhanced stromal vascular fraction and platelet-rich plasma improves fat grafting maintenance in breast reconstruction. Stem Cells Transl Med 2012;1:341-51. https://doi.org/10.5966/ sctm.2011-0065

14. Keyhan SO, Hemmat S, Badri AA, Abdeshahzadeh A, Khiabani K. Use of platelet-rich fibrin and platelet-rich plasma in combination with fat graft: which is more effective during facial lipostructure? J Oral Maxillofac Surg 2013;71:610-21. https://doi.org/10.1016/ j.joms.2012.06.176

15. Yoshimura K, Asano Y, Aoi N, Kurita M, Oshima Y, Sato K, et al. Progenitor-enriched adipose tissue transplantation as rescue for breast implant complications. Breast J 2010;16:169-75. https://doi. org/10.1111/j.1524-4741.2009.00873.x

16. Zocchi ML, Zuliani F. Bicompartmental breast lipostructuring. Aesthetic Plast Surg 2008;32:313-28. https://doi.org/10.1007/ s00266-007-9089-3

17. Tanna N, Wan DC, Kawamoto HK, Bradley JP. Craniofacial microsomia soft-tissue reconstruction comparison: inframammary extended circumflex scapular flap versus serial fat grafting. Plast Reconstr Surg 2011;127:802-11. https://doi.org/10.1097/ PRS.0b013e3181fed6e4

How to cite this article: Khorasani M, Janbaz P. Clinical evaluation of autologous fat graft for facial deformity: a case series study. J Korean Assoc Oral Maxillofac Surg 2021;47:286-290. https:// doi.org/10.5125/jkaoms.2021.47.4.286 